\title{
Risk Factors Associated with Spontaneous Abortion in Dr. Soetomo General Hospital Surabaya: a Case-control Study
}

\author{
Safira Zakira ${ }^{1)}$, Gatut Hardianto \\ ${ }^{1)}$ Fakultas Kedokteran Universitas Airlangga Surabaya
}

OPEN ACCESS

ISSN 2548-2246 (online)

ISSN 2442-9139 (print)

Edited by:

Paramitha Amelia K

Reviewed by:

Evi Wahyuntari

*Correspondence: Safira Zakira safirazakira-2017@fk.unair.ac.id

Received : 30 Desember 2020

Accepted : 05 Januari 2021

Published : 05 April 2021

Citation : Safira Zakira (2021)

Risk Factors Associated with

Spontaneous Abortion in Dr.

Soetomo General Hospital

Surabaya : a Case-control Study .

7:1. doi:

10.21070/midwiferia.v\%vi\%i.112

Kata kunci : Misscarriage, risk factors, spontaneus abortion

The Maternal Mortality Ratio (MMR) in Indonesia is still fairly high. One of the top three causes of maternal death is bleeding. Spontaneous abortion is an early pregnancy problem leading to the occurrence of bleeding and direct maternal death. The causes of spontaneous abortion vary and can be caused by multiple factors. Early identification of risk factors is necessary to reduce mortality and morbidity due to spontaneous abortion and its complications. This study's objective was to identify the risk factors of spontaneous abortion in Dr. Soetomo General Hospital. This study was an observational analytic with a case-control approach. The population was all pregnant women hospitalized at the Obstetrics and Gynaecology Department in Dr. Soetomo General Hospital from January 2017 to December 2018. The samples were 120 in total, included 40 cases and 80 controls taken by consecutive sampling. The data were analyzed using univariate and bivariate analysis with the Chi-square test. The results based on the bivariate analysis showed history of previous abortion $(\mathrm{p}<0.001)$, chronic maternal disease $(p<0.001)$, hemoglobin levels $(p=0.020)$, maternal age $(\mathrm{p}=0.026)$, gravidity $(\mathrm{p}=0.036)$, and infection $(\mathrm{p}=0.037)$ had significant correlation with spontaneous abortion. In conclusion, risk factors associated with spontaneous abortion in Dr. Soetomo General Hospital were history of previous abortion, chronic maternal disease, anemia, advanced maternal age, multigravidity, and infection. Positive pregnancy outcomes are expected to play a role in reducing MMR in Indonesia. Therefore, high-risk pregnant women are suggested to carry out regular Antenatal care recommendations with intensive supervision. 


\section{INTRODUCTION}

The Maternal Mortality Ratio (MMR) in Indonesia is considerably high. According to the Inter-Census Population Survey (SUPAS) in 2015, MMR in Indonesia reached 305 per 100,000 live births. In 2018, the MMR in East Java Province reached 91.45 per 100,000 live births. According to East Java Provincial Health Office, the three highest causes of maternal death in East Java Province are the result of other causes (32.57\%), pre-eclampsia/ eclampsia (31.32\%), and bleeding (22.8\%).

Bleeding in pregnancy occurs at an early gestational age or later in pregnancy. Spontaneous abortion is one of the causes of bleeding in early pregnancy. The National Center for Health Statistics, the Centers for Disease Control and Prevention, and WHO define spontaneous abortion as spontaneous pregnancy loss before 20 weeks of gestation or a fetus weighing less than 500 grams (Cunningham et al., 2018).

Around $75 \%$ of the incidence of spontaneous abortion happens when gestational age is less than 16 weeks, and $80 \%$ of this percentage occurs before gestational age reaches 12 weeks (Konar, 2015). According to National Health Service, spontaneous abortion occurs in at least 15-20\% of pregnancies, meaning that one in 8 pregnancies is at risk of becoming an abortion. The incidence of abortion in Indonesia reached over more than 2.3 million per year (Akbar, 2019).

The causes of spontaneous abortion vary widely and can be caused by a combination of various factors (multi factors). In theory, there are risk factors that are thought to increase the risk of spontaneous abortion occurrence. Some of these risk factors include fetal, maternal, paternal, social-behavioral, and occupationalenvironmental factors.

Fetal factors include chromosomal abnormalities, placental abnormalities, and embryos with local abnormalities (Sastrawinata et al., 2005). The most common maternal factors that cause spontaneous abortion are advanced maternal age, high parity, multigravidity, history of previous abortion, obesity or underweight, infection, uterine abnormalities, chronic maternal disease, and anemia (Cunningham et al., 2018; Edmonds et al. ., 2018; Fraser et al., 2011; Johnson et al., 2015; Konar, 2015; Prawirohardjo, 2010; Sastrawinata et al., 2005). Social-behavioral risk factors include the consumption of cigarettes, alcohol, caffeine, drugs, and the use of contraception 
(Johnson et al., 2015; Konar, 2015).

Occupational-environmental factors come from exposure to radiation and chemicals (Sastrawinata et al., 2005). Paternal factors such as sperm abnormalities are also associated with spontaneous abortion (Konar, 2015).

Spontaneous abortion can lead to severe complications. According to Sujiyatini (2009), complications of spontaneous abortion include bleeding, uterine perforation, infection, and shock. Prevention efforts are needed to be done to reduce mortality and morbidity due to abortion and its complications. One way is to identify spontaneous abortion risk factors early. This action is expected to help lower the number of MMR. The Medium-Term National Development Plan (RPJMN) targeted to reduce national MMR to 183 cases per 100,000 live births in 2024 .

Dr. Soetomo General Hospital Surabaya is one of the hospitals located in East Java Province as the central hospital of reference for Indonesia's eastern part. The incidence of spontaneous abortion in Dr. Soetomo General Hospital Surabaya is quite a lot. According to the research of Setiyawati (2013), the number of spontaneous abortion incidence in 2012 was 553 cases in total. This study aimed to determine the risk factors associated with spontaneous abortion in Dr. Soetomo General Hospital Surabaya.

\section{METHODS}

This research was an observational analytic with a case-control approach. This retrospective study used secondary data collected from Dr. Soetomo General Hospital Obstetrics and Gynecology Inpatient Installation's medical records. The population was all pregnant women who had been hospitalized at Dr. Soetomo General Hospital Obstetrics and Gynecology Inpatient Installation during the period from January 2017 - December 2018. The samples were 120, which included 40 patients as cases and 80 patients as controls (cases to controls ratio of $1: 2)$.

The sampling technique was consecutive sampling. The data analysis used univariate and bivariate analysis with Chi-square test, degree of significance $\alpha=0.05$. The Risk Estimate test was conducted to obtain the Odds Ratio (OR) value by interpreting a $95 \%$ Confidence Interval (CI). Statistical tests were performed using SPSS statistical data processing software version 25 . 


\section{RESULTS}

Forty cases from a total of 136 available cases of spontaneous abortion were included in this study. Based on the study results, the type of spontaneous abortion was mostly incomplete abortion, as many as 21 cases (52.5\%) followed by 8 cases of complete abortion (20.0\%), 7 cases $(17.5 \%)$ of missed abortion, 2 cases of recurrent miscarriage $(5.0 \%)$, and one case each for septic abortion and threatened miscarriage $(2.5 \%)$.

\section{Univariate Analysis}

The univariate analysis results are listed in Table 1. Based on Table 1, the majority of spontaneous abortion cases occurred in mothers aged less than 35 years $(67.5 \%)$, low risk parity (62.5\%), multigravidas (72.5\%), had a history of abortion (57.5\%), low risk BMI (70.0\%), had no infection (77.5\%), did not have uterine abnormalities (89.6\%), had chronic maternal disease (57.5\%), not anemic $(80.0 \%)$, and had no fetal anomalies $(90.0 \%)$, and no placental abnormalities $(95.0 \%)$.
While the distribution of respondents in the majority control group was mothers aged less than 35 years $(85.0 \%)$, low risk parity (76.25\%), multigravidas (52.5\%), had no history of abortion (86.25\%), low risk BMI (80.0\%), had no infection (91.25\%), did not have uterine abnormalities (100.0\%), did not have chronic maternal disease $(77.5 \%)$, not anemic (95.0\%), and no fetal anomalies $(93.75 \%)$, and no placental abnormalities (98.75\%). 
Table 1. The distribution of respondents by maternal and fetal characteristic

\begin{tabular}{|c|c|c|c|c|c|c|}
\hline \multirow{2}{*}{ Characteristics } & \multicolumn{2}{|c|}{ Case } & \multicolumn{2}{|c|}{ Control } & \multicolumn{2}{|c|}{ Total } \\
\hline & $\mathbf{n}$ & $\%$ & $\mathbf{n}$ & $\%$ & $\mathbf{n}$ & $\%$ \\
\hline \multicolumn{7}{|l|}{ Maternal Characteristics } \\
\hline \multicolumn{7}{|l|}{ Maternal age } \\
\hline High-risk group ( $\geq 35$ years of age) & 13 & 32.5 & 12 & 15.0 & 25 & 20.83 \\
\hline Low-risk group $(<35$ years of age $)$ & 27 & 67.5 & 68 & 85.0 & 95 & 79.17 \\
\hline Total & 40 & 100.0 & 80 & 100.0 & 120 & 100.0 \\
\hline \multicolumn{7}{|l|}{ Parity } \\
\hline High-risk group (P1 and $\geq P 4)$ & 15 & 37.5 & 19 & 23.75 & 34 & 28.33 \\
\hline Low-risk group (P0 and $\mathrm{P} 2-3$ ) & 25 & 62.5 & 61 & 76.25 & 86 & 71.67 \\
\hline Total & 40 & 100.0 & 80 & 100.0 & 120 & 100.0 \\
\hline \multicolumn{7}{|l|}{ Gravidity } \\
\hline High-risk group (Multigravida) & 29 & 72.5 & 42 & 52.5 & 71 & 59.17 \\
\hline Low-risk group (Primigravida) & 11 & 27.5 & 38 & 47.5 & 49 & 40.83 \\
\hline Total & 40 & 100.0 & 80 & 100.0 & 120 & 100.0 \\
\hline \multicolumn{7}{|l|}{ History of previous abortion } \\
\hline High-risk group ( $\geq \mathrm{A} 1)$ & 23 & 57.5 & 11 & 13.75 & 34 & 28.33 \\
\hline Low-risk group (A0) & 17 & 42.5 & 69 & 86.25 & 86 & 71.67 \\
\hline Total & 40 & 100.0 & 80 & 100.0 & 120 & 100.0 \\
\hline \multicolumn{7}{|l|}{ Body Mass Index } \\
\hline High-risk group (Underweight and obese) & 12 & 30.0 & 16 & 20.0 & 28 & 23.33 \\
\hline Low-risk group (Normal and overweight) & 28 & 70.0 & 64 & 80.0 & 92 & 76.67 \\
\hline Total & 40 & 100.0 & 80 & 100.0 & 120 & 100.0 \\
\hline \multicolumn{7}{|l|}{ Infection } \\
\hline High-risk group (Yes) & 9 & 22.5 & 7 & 8.75 & 16 & 13.33 \\
\hline Low-risk group (No) & 31 & 77.5 & 73 & 91.25 & 104 & 86.67 \\
\hline Total & 40 & 100.0 & 80 & 100.0 & 120 & 100.0 \\
\hline \multicolumn{7}{|l|}{ Uterine abnormalities } \\
\hline High-risk group (Yes) & 4 & 10.0 & 0 & 0.0 & 4 & 3.33 \\
\hline Low-risk group (No) & 36 & 90.0 & 80 & 100 & 116 & 96.67 \\
\hline Total & 40 & 100.0 & 80 & 100.0 & 120 & 100.0 \\
\hline \multicolumn{7}{|l|}{ Chronic maternal disease } \\
\hline High-risk group (Yes) & 23 & 57.5 & 18 & 22.5 & 41 & 34.17 \\
\hline Low-risk group (No) & 17 & 42.5 & 62 & 77.5 & 79 & 65.83 \\
\hline Total & 40 & 100.0 & 80 & 100.0 & 120 & 100.0 \\
\hline \multicolumn{7}{|l|}{ Hemoglobin levels } \\
\hline High-risk group (Anemia) & 8 & 20.0 & 4 & 5.0 & 12 & 10.0 \\
\hline Low-risk group (Normal) & 32 & 80.0 & 76 & 95.0 & 108 & 90.0 \\
\hline Total & 40 & 100.0 & 80 & 100.0 & 120 & 100.0 \\
\hline \multicolumn{7}{|l|}{ Fetal Characteristics } \\
\hline \multicolumn{7}{|l|}{ Fetal anomalies } \\
\hline High-risk group (Yes) & 4 & 10.0 & 5 & 6.25 & 9 & 7.5 \\
\hline Low-risk group (No) & 36 & 90.0 & 75 & 93.75 & 111 & 92.5 \\
\hline Total & 40 & 100.0 & 80 & 100.0 & 120 & 100.0 \\
\hline \multicolumn{7}{|l|}{ Placental abnormalities } \\
\hline High-risk group (Yes) & 2 & 5.0 & 1 & 1.25 & 3 & 2.5 \\
\hline Low-risk group (No) & 38 & 95.0 & 79 & 98.75 & 117 & 97.5 \\
\hline Total & 40 & 100.0 & 80 & 100.0 & 120 & 100.0 \\
\hline
\end{tabular}


2 Table 2. Results of the bivariate analysis

\begin{tabular}{|c|c|c|}
\hline Variable & P-value & $\begin{array}{l}\text { OR } \\
(95 \% \mathrm{CI})\end{array}$ \\
\hline $\begin{array}{l}\text { Maternal age } \\
\text { High-risk } \\
\text { Low-risk }\end{array}$ & 0.026 & $\begin{array}{l}2.728 \\
(1.107-6.727)\end{array}$ \\
\hline $\begin{array}{l}\text { Parity } \\
\text { High-risk } \\
\text { Low-risk }\end{array}$ & 0.115 & $\begin{array}{l}1.926 \\
(0.847-4.380)\end{array}$ \\
\hline $\begin{array}{l}\text { Gravidity } \\
\text { High-risk } \\
\text { Low-risk }\end{array}$ & 0.036 & $\begin{array}{l}2.385 \\
(1.049-5.422)\end{array}$ \\
\hline $\begin{array}{l}\text { History of previous abortion } \\
\text { High-risk } \\
\text { Low-risk }\end{array}$ & $<0.001$ & $\begin{array}{l}8.487 \\
(3.474-20.733)\end{array}$ \\
\hline $\begin{array}{l}\text { Body Mass Index } \\
\text { High-risk } \\
\text { Low-risk }\end{array}$ & 0.222 & $\begin{array}{l}1.714 \\
(0.718-4.093)\end{array}$ \\
\hline $\begin{array}{l}\text { Infection } \\
\text { High-risk } \\
\text { Low-risk }\end{array}$ & 0.037 & $\begin{array}{l}3.028 \\
(1.035-8.857)\end{array}$ \\
\hline $\begin{array}{l}\text { Uterine abnormalities } \\
\text { High-risk } \\
\text { Low-risk }\end{array}$ & 0.011 & - \\
\hline $\begin{array}{l}\text { Chronic maternal disease } \\
\text { High-risk } \\
\text { Low-risk }\end{array}$ & $<0.001$ & $\begin{array}{l}4.660 \\
(2.058-10.555)\end{array}$ \\
\hline $\begin{array}{l}\text { Hemoglobin levels } \\
\text { High-risk } \\
\text { Low-risk }\end{array}$ & 0.020 & $\begin{array}{l}4.750 \\
(1.335-16.902)\end{array}$ \\
\hline $\begin{array}{l}\text { Fetal anomalies } \\
\text { High-risk } \\
\text { Low-risk }\end{array}$ & 0.479 & $\begin{array}{l}1.667 \\
(0.422-6.582)\end{array}$ \\
\hline $\begin{array}{l}\text { Placental abnormalities } \\
\text { High-risk } \\
\text { Low-risk }\end{array}$ & 0.257 & $\begin{array}{l}4.158 \\
(0.366-47.297)\end{array}$ \\
\hline
\end{tabular}

3 Source : Medical Records 


\section{Bivariate Analysis}

Table 2. summarizes the results of the bivariate analysis Chi-square test $2 \times 2$ with the significance of $\alpha=0.05$ and Odds Ratio (OR) 95\% Confidence Interval (CI). Based on the results of the bivariate analysis with the Chisquare test, it was found that the independent variable with a significant p-value $(\mathrm{p}<0.05)$ were history of previous abortion $(\mathrm{p}=<0.001)$, chronic maternal disease $(\mathrm{p}=<0.001)$, uterine abnormalities $(\mathrm{p}=0.011)$, Hb level $(\mathrm{p}=0.020)$, maternal age $(\mathrm{p}=0.026)$, gravida $(\mathrm{p}=0.036)$, and infection $(\mathrm{p}=0.037)$, meaning Ho was rejected which can be interpreted that there was a significant relationship between abortion history, chronic maternal disease, uterine abnormalities, $\mathrm{Hb}$ level, maternal age, gravida, and infection with spontaneous abortion. The independent variables with a $\mathrm{p}$-value $\mathrm{p}>0.05$ were fetal anomalies $(\mathrm{p}=0.479)$, placental abnormalities $(\mathrm{p}=0.257)$, BMI $(\mathrm{p}=0.222)$, and the number of parity ( $\mathrm{p}=0.115)$, meaning Ho was accepted which can be interpreted that there was no significant relationship between fetal anomalies, placental abnormalities, BMI, and parity with spontaneous abortion.

The risk estimate test results obtained Odds Ratio (OR) value of history of abortion (OR = 8,487; 95\% CI 3,474 - 20,733), chronic maternal disease $(\mathrm{OR}=4,660 ; 95 \%$ CI 2,058 - 10,555), Hb levels ( $\mathrm{OR}=4,750 ; 95 \%$ CI 1,335 - 16,902) , maternal age $(\mathrm{OR}=2.728 ; 95 \%$ CI 1.107 6.727), gravida $(\mathrm{OR}=2.385 ; 95 \%$ CI 1.049 5.422), and infection (OR $=3.028 ; 95 \%$ CI 1.035 - 8.857) had OR value > 1 and the confidence interval does not include the value of 1 , meaning that history of abortion, chronic maternal disease, $\mathrm{Hb}$ level, maternal age, gravida, and infection were risk factors for spontaneous abortion. The results of the risk estimate test for the uterine abnormality variable could not obtain an OR value because there was a cell count of 0 in the data for the control group with uterine abnormalities. Thus, uterine abnormalities could not be determined as a risk factor for spontaneous abortion.

\section{DISCUSSION}

\section{Maternal Age}

The statistical analysis showed that the mean maternal age of the case group $(31.0 \pm 6.397)$ was higher than the control group (27.58 \pm $6.527)$ and the proportion of high-risk groups ( $\geq$ 35 years old) were more numerous in the case group (32.5\%) compared to control group $(15.0 \%)$. Chi-square test result indicated that there was a significant association between maternal age and spontaneous abortion ( $\mathrm{p}=$ 
0.026, $\mathrm{p}<0.05)$. According to the risk estimate test result, risk calculation obtained an OR of 2.728 (95\% CI: 1.107 to 6.727$)$, meaning pregnant women aged $\geq 35$ years may increase the risk of spontaneous abortion up to 2.728 times compared to pregnant women aged less than 35 years. These results are consistent with the previous research conducted by Maconochie et al. (2007), which stated that high-maternal age was independently associated with increased risk of spontaneous abortion.

The incidence rate of spontaneous abortion in older women is higher, mainly caused by the impairment of oocyte quality, chromosome segregation defects, and aneuploidy (Mills and Lavender, 2014). Advanced maternal age is associated with the reduction in the number and quality of remaining oocytes. At the age of 30 to 35 years, the number of oocytes reduces to about 100,000 . The process of oocyte maturation and ovulation becomes insufficient because of the continuous loss of functional oocytes (Casanova et al., 2019). In addition, advanced age pregnant women also have a greater risk of recurrent miscarriage (Johnson et al., 2015).

\section{Number of parity}

The statistical analysis result showed that the mean number of parity of the case group (1.08 \pm 1.228) was higher than the control group $(0.85 \pm$ 1.115) and the proportion of high-risk groups (P1 and $\geq \mathrm{P} 4$ ) were more numerous in the cases $(37.5 \%)$ compared to the control group $(23.75 \%)$. However, the Chi-square test result indicated no significant association between the number of parity and spontaneous abortion $(\mathrm{p}=$ $0.115, \mathrm{p}>0.05)$. The previous research conducted by Qubro et al. (2018) is in accordance with our study's results, which concluded that there was no association between parity and spontaneous abortion at the Abdul Moeloek Bandar Lampung Hospital $(\mathrm{p}=0.298)$. These results differ from Meti (2012) research in the RSIA Mutiara Hati Pringsewu, which stated a significant relationship between parity and the incidence of spontaneous abortion $(\mathrm{p}=0.000)$. The difference in this study results may be due to the possibility of a spontaneous abortion caused by factors other than parity. In addition, women who have given birth before tend to maintain their pregnancy better because of their previous successful pregnancy experience. 
According to Wiknjosastro (2005), the maternal mortality ratio is higher in primiparous and multiparous women. The higher the parity, the higher the chance of the unfavorable uterine endometrium, the greater the risk of pregnancy complications (Prawirohardjo, 2010). The former placental implantation in past pregnancies causes tissue degeneration and necrosis. The decreased function and vascularity in the endometrium cause insufficient oxygenation and nutrient supply to products of conception (POC), and the circulation to the fetus is impaired (Manuaba, 2002).

\section{Gravidity}

The statistical analysis showed that the case group's mean gravidity $(2.90 \pm 1.780)$ was higher compared to the control group $(2.00 \pm 1.222)$ and the proportion of high-risk groups (multigravida) were more numerous in the case group $(72.5 \%)$ than control group (52.5\%). Chi-square test result indicated that there was a significant association between the number of gravidities and spontaneous abortion $(\mathrm{p}=0.036, \mathrm{p}<0.05)$. According to the risk estimate test result, risk calculation obtained an OR value of 2.385 (95\% CI: 1.049 to 5.422 ), meaning that multigravidity may increase the risk of spontaneous abortion up to 2.385 times. These results are supported by Purwaningrum \& Fibriyana (2017) research in
Temanggung District General Hospital, which stated that gravidity is a risk factor for spontaneous abortion $(\mathrm{p}=0.025)$.

Multigravida significantly has a greater risk for spontaneous abortion than primigravida (Fraser et al., 2011). According to LlewellynJones (2002), the number of spontaneous abortion cases increases along with the increasing number of gravidity. Increased gravidity is associated with decreased endometrial function and vascularization in the uterine body, which resulted in weak implantation of the product of conception leading to expulsion of a part of or all of the product of conception (Purwaningrum \& Fibriyana, 2017).

\section{History of previous abortion}

The results showed that the mean history of abortion in the case group $(0.88 \pm 1.017)$ was higher than the average history of abortion in the control group $(0.15 \pm 0.393)$, and the proportion of high-risk groups were found more numerous in the cases $(57.5 \%)$ than controls $(13.75 \%)$. Chi-square test results showed a significant association between abortion history of previous spontaneous abortion $(\mathrm{p}=<0.001, \mathrm{p}<0.05)$. According to the risk estimate test result, risk calculation obtained an OR of 8.487 (95\% CI: 3.474 to 20.733), which means that having a 
history of abortion is a risk factor for spontaneous abortion. Pregnant women with a history of previous abortion may increase the risk of spontaneous abortion 8.487 times. The results of a similar study by Putri (2018) showed an association between a history of spontaneous abortion with the incidence of spontaneous abortion in Medika Aghisna Public Hospital of Cilacap $(p=0,020)$. Mothers who have experienced abortion are five times more likely to undergo abortion in subsequent pregnancies $(\mathrm{OR}=5.870)$.

The results are consistent with the theory, according to Edmonds et al. (2018), which stated that the more history of abortion had ever experienced, the greater the risk of abortion in subsequent pregnancies. According to Prawirohardjo (2010), after suffering a spontaneous abortion once, the risk for abortion in the future is around $15 \%$. The risk would increase to $25 \%$ if abortion happened twice.

Surgical management (curettage) in the previous abortion increases the incompetent cervix's risk because of continuous muscle stimulation to keep the cervical area open. The procedure can also change the muscle's permeability affecting the decidua basalis in the implantation process of subsequent pregnancy (Purwaningrum \&
Fibriyana, 2017).

\section{Body Mass Index (BMI)}

The proportion of high-risk groups (underweight or obese) were more numerous in cases $(30.0 \%)$ than controls $(20.0 \%)$. Chi-square statistical test result indicated no significant relationship between BMI and spontaneous abortion $(p=0.222, p>0.05)$. This result is in line with Silitonga et al. (2017) research, which showed no significant relationship between BMI with abortion in the General Hospital Center Dr. Mohammad Hoesin Palembang. However, these results were contradictory with Metwally (2010) results, which stated a relationship between BMI and the occurrence of spontaneous abortion.

This result can be explained because this research only used BMI data after pregnancy. Data quality would be better if the BMI data were compared with prepregnancy BMI. According to Diouf et al. (2011), BMI can help understand the relationships between maternal nutritional status and the fetus' growth. Any maternal weight changes before pregnancy can be used as a reference to identify the preconception energy balance and nutritional status.

Cunningham et al. (2018) stated that pregnant women with obesity have high 
maternal complications, increasing the risk of spontaneous abortion. Obesity in pregnancy increases the risk of leptin resistance, which can inhibit the fetus's growth (Hacker et al., 2016). Increased risk of miscarriage in women who are obese may also have relationships with insulin resistance (Johnson et al., 2015).

If the mother is malnourished during pregnancy, the risk and complications of pregnancy include bleeding, lack of weight gain, and infection susceptibility. Low nutritional status can affect fetal growth in the womb leading to abortion, stillbirth, congenital abnormalities, anemia, neonatal mortality, and low birth weight (LBW) (Waryana, 2010).

\section{Infection}

The proportion of high-risk groups (infection) was found more numerous in the case group $(22.5 \%)$ than control $(8.75 \%)$. Chi-square test results showed a significant association between infection with spontaneous abortion at Hospital Dr. Soetomo $(\mathrm{p}=0.037, \mathrm{p}<0.05)$. According to the risk estimate test result, risk calculation obtained an OR of 3.028 (95\% CI: 1.035 to 8.857$)$, meaning that infection increases the risk of spontaneous abortion 3.028 times higher. This result is supported by Octarina et al. (2018) research results at the Dr. Rasidin Hospital and RSIA Siti Hawa Padang, which showed a relationship between $\mathrm{C}$. trachomatis infection and spontaneous abortion $(\mathrm{p}=0.025)$.

Prawirohardjo (2010) stated that the presence of toxic metabolites, endotoxins, exotoxins, and cytokines directly impact the fetoplacental unit. Infection of the fetus may result in fetal death or severe disability that raises fetal survival difficulties. Infection of the placenta can lead to placental insufficiency and may continue until the death of the fetus.

Chronic endometrial infection interferes with implantation, amnionitis, and genetic and anatomical changes in the embryo. Infection generally occurs because of virus infection during early pregnancy.

\section{Uterine Abnormalities}

The proportion of high-risk groups were more numerous in the case group $(10.0 \%)$ than in control group (0.0\%). Chi-square test results showed a significant relationship between uterine abnormalities with spontaneous abortion at Hospital Dr. Soetomo ( $\mathrm{p}=0.011, \mathrm{p}<0.05)$. However, the risk of having uterine abnormalities towards the incidence of spontaneous abortion in Dr. Soetomo General Hospital could not be determined because there was a cell count with a value of 0 therefore excluded as a risk factor for spontaneous abortion. 
The uterine abnormalities found in this study were one case of congenital uterine abnormalities (septum uteri) and 3 cases of acquired uterine abnormality (myoma uteri). Leiomyoma or myoma uteri can cause spontaneous abortion. In most cases, the location of myomas is more influential than its size. Myoma uteri, primarily located near the placental implantation, can interfere with implantation (Cunningham et al., 2018). Submucosal fibroids have a more significant role than other types (Casanova et al., 2019). According to Konar (2015), submucosal myoma uteri is associated with distortion or partial obliteration of the uterine cavity.

Some congenital abnormalities such as uterine unicornis, bicornis, and septate uteri may increase the risk of miscarriage in the first trimester, mid-trimester abortion, or premature labor. Abnormalities of uterine development is a consequence of an abnormal formation or fusion of the Mullerian duct (Cunningham et al., 2018). Congenital malformations of the uterine septum may lead to abortion because of the reduced volume of intra-uterine, reduced placental vascularization, reduced uterine expansion capabilities, and increased uterine irritability / contractility (Konar, 2015).

\section{Maternal Chronic Disease}

The proportion of high-risk groups were found more numerous in the case group (57.5\%) than in the control group $(22.5 \%)$. Chi-square test results showed a significant association between maternal chronic disease with spontaneous abortion at Hospital Dr. Soetomo ( $p$ $=<0.001, \mathrm{p}<0.05)$. According to the risk estimate test result, risk calculation obtained an OR of 4.660 (95\% CI: 2.058 to 10.555$)$, meaning that pregnant women with maternal chronic disease may increase the risk of spontaneous abortion 4.660 times higher. The results of this study are similar to the results of Rangkuti et al. (2019) shows that there were influences of maternal disease $(\mathrm{p}=0.0001) \mathrm{OR}=26.0(95 \%$ CI 8.79 to 76.8 ) with the incident threatened abortion in the General Hospital Padangsidimpuan City.

Sinclair (2009) stated that one of the risk factors for spontaneous abortion is chronic medical problems. According to Cunningham et al. (2018), maternal diseases that have a prominent risk of spontaneous abortion include uncontrolled diabetes mellitus, obesity, thyroid disease, and autoimmune disease. Maternal chronic diseases such as hypertension, kidney disease, liver disease, diabetes mellitus can 
directly affect fetal growth through the placenta (Manuaba, 2002).

\section{Hemoglobin (Hb) Levels}

Distribution respondents of both case and control groups almost entirely were not anemic mothers $($ cases $=80.0 \%$; control $=95.0 \%)$. The proportion of high-risk groups were found more numerous in the case group (20.0\%) than in the control group $(5.0 \%)$. Chi-square test results showed a significant association between $\mathrm{Hb}$ levels and spontaneous abortion in Dr. Soetomo General Hospital ( $\mathrm{p}=0,020, \mathrm{p}<0.05)$. According to the risk estimate test result, risk calculation obtained an OR of 4.750 (95\% CI: 1.335 to 16.902 ), which means that pregnant women with anemia may increase the risk of spontaneous abortion 4.750 times higher. This result is supported by Amalia and Sayono (2015) results in the Islamic Hospital Sultan Agung Semarang, which showed a significant relationship between anemia with complete and incomplete spontaneous abortion $(\mathrm{p}=0.019)$. Pregnant women who suffer from anemia are at risk of experiencing abortion 2.547 times than respondents without anemia $(\mathrm{OR}=2.547)$.

The results are consistent with the theory from Manuaba (2002), which stated that anemia could directly impact the fetus through the placental growth due to nutritional and circulation disorders to the uteroplacental. According to Akbar (2019), iron deficiency anemia in pregnancy increases the incidence of spontaneous abortion. Iron is one of the essential elements in hematopoiesis, a hemoglobin synthesis in red blood cells. Pregnant women with iron deficiency anemia can not give sufficient iron stores for the fetus in the first few months of pregnancy.

According to Widianti (2017), low hemoglobin levels cause the decreased supply of oxygen to the mother and fetus metabolism hence the decreased blood oxygen level. If the situation takes place for a long time can lead to tissue necrosis, resulting in conception products can not survive long enough in the womb.

\section{Fetal Anomalies}

The distribution of respondents both in case and control groups were almost entirely did not have fetal anomalies (cases $=90.0 \%$; control $=$ $93.75 \%)$. The proportion of high-risk groups found more numerous in the cases $(10.0 \%)$ than controls (6.25\%). Chi-square test results showed no significant association between fetal anomalies with spontaneous abortion at Dr. Soetomo General Hospital ( $\mathrm{p}=0.479, \mathrm{p}>0.05)$.

These results can be explained by Leveno (2009) theory, which stated around $60 \%$ of spontaneous abortion incidence are caused by 
chromosomal abnormalities. In this study, none of the cases taken were found with chromosomal abnormalities. This is most likely because the samples had not been examined to detect fetal chromosomal abnormalities because spontaneous abortion often happens before the mothers realized that they were already pregnant.

Screening test for chromosomal abnormalities can be done around week 11 to 13 in the first trimester of pregnancy. The test includes a simple maternal blood test and an ultrasound (CDC, 2020).

\section{Placental Abnormalities}

Distribution of respondents both case and control groups almost entirely had no placental abnormalities $($ cases $=95.0 \%$; control $=$ 98.75\%). The proportion of high-risk groups found more numerous in the case group $(5.0 \%)$ than in the control group (1.25\%). Chi-square test results showed no significant correlation between placental abnormalities with spontaneous abortion at Dr. Soetomo General Hospital ( $\mathrm{p}=0.257, \mathrm{p}>0.05)$.

The type of placental abnormalities found in this study was placenta previa. Placenta previa is the most common type of abnormal placentation. However, placenta previa is generally more associated with antepartum bleeding in late pregnancy than spontaneous abortion. The incidence of bleeding from a placenta previa accounts for $20 \%$ of all antepartum hemorrhage cases (Hacker et al., 2016).

According to the theory described by Cunningham et al. (2018), placental abnormalities such as placenta previa can cause mid-trimester spontaneous abortion. Placental functional impairment, vascular and circulatory disorders can lead to spontaneous abortion (Manuaba, 2002).

\section{CONCLUSION}

This study showed that a history of previous abortion, chronic maternal disease, anemia, advanced maternal age, multigravidity, and infection were risk factors associated with the occurrence of spontaneous abortion in Dr. Soetomo General Hospital Surabaya.

Positive pregnancy outcomes are expected to play a role in reducing MMR in Indonesia. Therefore, pregnant women are suggested to carry out regular antenatal care recommendations, and high-risk pregnant women need to receive more intensive supervision. 


\section{REFFERENCES}

Akbar, A. (2019). Faktor Penyebab Abortus Di Indonesia Tahun 2010 - 2019: Studi Meta Analisis. Jurnal Biomedik (JBM). 11(3). 182-

191. doi: 10.35790/jbm.11.3.2019.26660. Retrieved from https://ejournal.unsrat.ac.id/index.php/biomedi $\underline{\mathrm{k} / \mathrm{article} / \mathrm{view} / 26660}$

Casanova, R. (2019). Beckmann and Ling's obstetrics and gynecology. $8^{\text {th }}$ Ed. Philadelphia: Wolters Kluwer.

Centers for Disease Control and Prevention. (2020).

Diagnosis of Birth Defects. Retrieved from https://www.cdc.gov/ncbddd/birthdefects/diag nosis.html

Cunningham, F.G., K.J. Leveno, S.L. Bloom, J.S. Dashe, B.L. Hoffman, B.M. Casey, C.Y. Spong. (2018). Williams Obstetrics, 25th Ed.

New York: McGraw-Hill Education.

Diouf, Ibrahima, et al. (2011). Maternal Weight Change Before Pregnancy In Relation To Birthweight And Risks Of Adverse Pregnancy Outcomes. Perinatal Epidemiology, Vol. 26, 789-796. $\quad$ Retrieved from https://pubmed.ncbi.nlm.nih.gov/21710259/

Edmonds, D.K., C. Lees, T. Bourne. (2018). Dewhurst's textbook of obstetrics \& gynecology, $9^{\text {th }}$ Ed. New Jersey: John Wiley \& Sons Ltd.
Fraser, D.M. dan M.A. Cooper. (2011). Buku Ajar Bidan, Edisi 14. Jakarta: EGC.

Hacker N.F., J.C. Gambone, C.J. Hobel. (2016). Hacker \& Moore's Essentials of Obstetrics and Gynecology. $6^{\text {th }}$ Ed. Elsevier.

Johnson, C.T., J.L. Hallock, J.L. Bienstock, H.E. Fox, E.E. Wallach. (2015). The johns hopkins manual of gynecology and obstetrics. $5^{\text {th }} \mathrm{Ed}$. Wolters Kluwer.

Konar, H., 2015. DC Dutta's textbook of obstetric. . $5^{\text {th }}$ Ed. Jaypee Brothers Medical Publishers (P) Ltd.

Leveno K.J., F.G. Cunningham, N.F. Gant, et al. (2009). Obstetri Williams: Panduan Ringkas, Edisi 21. Jakarta : EGC.

Manuaba. (2002). Ilmu Penyakit Kandungan dan Keluarga Berencana Untuk Pendidikan Bidan. Jakarta: Rineka Cipta.

Mills, T., \& Lavender, T. (2014). Advanced maternal age. Obstetrics, Gynaecology and Reproductive Medicine, 24(3), 85-90. Elsevier Prawirohardjo, S. (2010). Ilmu kebidanan Sarwono Prawirohardjo (Edisi Keempat, Cetakan Ketiga). Jakarta: PT Bina Pustaka Sarwono Prawirohardjo.

Purwaningrum, E.D. dan A. I. Fibriana. (2017). Faktor Risiko Kejadian Abortus Spontan. Higeia Journal Of Public Health Research And Development. 1(3), 84-94. Retrieved from 
https://journal.unnes.ac.id/sju/index.php/higeia /article/download/16968/8982/

Sastrawinata, S., D. Martaadisoebrata, F.F. Wirakusumah. (2005). Ilmu kesehatan reproduksi obstetri patologi. Edisi Kedua. Jakart: EGC.

Setiyawati. (2013). Gambaran kejadian abortus di RSUD Dr. Soetomo Surabaya tahun 2012. (skripsi). Retrieved from Repository Universitas Airlangga.

Sinclair. (2009). Buku Saku Kebidanan. Jakarta : EGC.

Sujiyatini. (2009). Asuhan Patologi Kebidanan. Yogyakarta: Pustaka Nuha Medika.

Waryana. (2010). Gizi Reproduksi. Yogyakarta: Pustaka Rihama.

Widianti L. (2017). Hubungan Anemia Defisiensi Besi pada Ibu Hamil dengan Kejadian Abortus di Ruangan Kasuari Rumah Sakit Umum Anutapura Palu. Jurnal Kesehatan, 8(1). 36. Retrieved from https://ejurnal.poltekkestjk.ac.id/index.php/JK/article/view/393

Wiknjosastro, Hanifa. (2005). Ilmu Kebidanan. Jakarta : Yayasan Bina Pustaka Sarwono Prawirohardjo. 